Animal behaviour

\section{Dumping eggs on conspecifics}

\section{N.B. Davies}

THE curious habits of the cuckoo ( Cuculus canorus) were known to Aristotle $\mathrm{e}^{1.2}$, who wrote about 2,300 years ago: "it lays its eggs in the nest of smaller birds . . . they do not sit, nor hatch, nor bring up their young". Gilbert White ${ }^{3}$ regarded this parasitic habit as a "monstrous outrage on maternal affection", and he dissected a cuckoo to see whether the crop lay unusually low in the body so as to make incubation uncomfortable. Finding no difference in structure from species which incubated their own eggs, he remarked "we are still at a loss for the cause". Since Darwin, naturalists have found the cuckoo's habit less puzzling and have wondered instead why more animals do not trick others into raising their offspring various populations of starlings (Sturnus vulgaris $)^{5}$, up to 24 per cent in colonies of cliff swallows (Hirundo pyrrhonota) ${ }^{7}$, 3-31 per cent in swallows (H. rustica $)^{10}$, and 18 per cent in a population of moorhens (Gallinula chloropus) ${ }^{8}$. Presumably, many instances of parasitism have gone undetected, and the use of DNA fingerprinting may reveal these figures as underestimates. In various species of ducks, the percentage may exceed 50 per cent of nests parasitized ${ }^{5}$ : in one study ${ }^{11}$ it reached 95 per cent.

Some of these high frequencies of parasitism have been recorded in populations breeding at unusually high densities because of the provision of nest boxes ${ }^{11}$. The nests parasitized are also often those
In cliff swallows, as in other species ${ }^{5,8}$, parasitic females adopt a mixed strategy of raising some of their own young and dumping some eggs parasitically. It will be interesting to see whether different females show varying degrees of parasitic behaviour and whether any, like the cuckoo, are professional parasites. The effects of brood parasitism on both host and parasite reproductive success need to be quantified. In some species, hosts can recognize conspecific eggs which are not their own and eject them from the nest ${ }^{14,15}$, whereas in others eggs are ejected only if they appear in the nest before the host begins to lay — after this, parasitic eggs are accepted ${ }^{10,16,17}$.

Brown and Brown suggest ${ }^{6}$ that dumping eggs is the way a bird avoids putting all its eggs in one basket; in a risky environment spreading eggs in several nests may increase the chance that at least some young survive. However, recent theoretical models suggest ${ }^{18}$ that selection for this form of bet-hedging is weak. A more

\section{IMAGE UNAVAILABLE FOR COPYRIGHT REASONS}

Changelings in the nest - the monstrous young cuckoo being fed by a dutiful yellow wagtail (left), is easily identified, but it is impossible to see whether one of a brood of cliff swallows (right) is an intruder. (Cuckoo: Frank Lane Picture Agency. Cliff swallows courtesy of Charles and Mary Brown.)

and so avoid the costs of parental care. Recent observations ${ }^{4.5}$ show that brood parasitism is, in fact, much commoner than previously supposed. Within several species of birds, some individuals play at cuckoos and lay eggs in the nests of conspecifics. On page 66 of this issue ${ }^{6}$, Charles and Mary Brown show, for the first time, that intraspecific brood parasitism can take place not only by direct laying of eggs in other nests, but also by the transfer of partly incubated eggs from the parasite's own nest.

Brood parasitism within a species has been detected by direct observations ${ }^{7}$ of females laying in other individuals' nests and also, indirectly, by the appearance of more than one egg per day during the laying of a clutch ${ }^{5.7}$ (each female lays only one egg per day); by the occurrence of eggs different in shape and colour from those of the host female ${ }^{8}$ (in some species each female lays distinctive eggs); and by maternity exclusion using electrophoresis? The proportion of nests parasitized has been estimated as 5-46 per cent for of near neighbours ${ }^{7,10}$. This result raises the question of whether laying eggs in other nests arises simply as mistaken nest identity rather than as an adaptation favoured by natural selection. The observation reported in this issue ${ }^{6}$ by Brown and Brown of female cliff swallows transporting partly incubated eggs from their own nests to the nests of other females supports the second interpretation, at least for this species; such specialized behaviour seems hardly likely to represent a mistake. Furthermore, intraspecific parasites adopt other tactics which seem to increase the success of parasitism. Both starlings $^{12}$ and cliff swallows ${ }^{6}$ sometimes remove host eggs before depositing their own, which may result in their offspring receiving better parental care. Parasitic laying in starlings occurs later in the day than the peak period of laying ${ }^{13}$, when the hosts are more likely to be at their nests and able to evict intruders. Finally, parasites can lay their eggs remarkably quickly? Interestingly, all these last three tactics are also adopted by cuckoos. likely explanation, perhaps, is that parasites increase their lifetime reproductive success by reducing the costs of parental care.

1. Aristotle (ed. Peck, A.L.) Historia Animalium Vol. II (Heinemann, London, 1970).

2. Aristotle (ed. Hett, W.S.) On Marvellous Things Heard (Heinemann, London, 1936)

3. White, G. The Natural History of Selborne (White, London, 1788-89)

Yom-Tov, Y Bio, Rev. 55, 93-108 (1980)

5. Andersson, M. in Producers and Scroungers: Strategies of Exploitation and Parasitism (ed. Barnard, C.J.) 195-228 (Croom Helm, London, 1984).

6. Brown, C.R. \& Brown, M.B. Nature 331, 66-68 (1988)

7. Brown, C.R. Science 224, 518-519 (1984).

8. Gibbons, D.W. Behav. Ecol. Sociobiol. 19, 221-232 (1986).

9. Gowaty, P.A. \& Karlin, A.A. Behav, Ecol. Sociobiol. $15,91-95$ (1984)

10. Møller, A.P. Anim. Behav. 35, 247-254 (1987).

11. Semel, B. \& Sherman, P.W. Auk 103, 813-816 (1986).

12. Feare, C.J. The Starling (Oxford University Press, 1984)

13. Feare, C.J., Spencer, P.L. \& Constantine, D.A.T. Ibis 124, 174-178 (1982)

14. Bertram, B.C.R. Nature 279, 233-234 (1979)

15. Victoria, J.K. Ibis 114, 367-376 (1972)

16. Emlen, S.T. \& Wrege, P.H. Ethology 71, 2-29 (1986).

17. Stouffer, P.C., Kennedy, E.D. \& Power, H.W. Anim Behav. 35, 1583-1584 (1987)

18. Bulmer, M.G. J. theor. Biol. 106, 529-535 (1984)

N.B. Davies is in the Zoology Department, University of Cambridge, Cambridge CB2 3EJ, $U K$. 